\title{
The Opposition of Confucians to Catholicism in the Early Qing Dynasty: Yang Guangxian and Kangxi Calendar Lawsuit (1664-1665)
}

\author{
Li Xuetao 李雪濤*
}

That which is recognized now as true has also its latent false side which will later manifest itself, just as that which is now regarded as false has also its true side by virtue of that which it could previously be regarded as true. Ludwig Feuerbach and the End of Classical German Philosophy, Friedrich Engels

During the $3^{\text {rd }}$ and $4^{\text {th }}$ year of the reign of Emperor Kangxi (1664-1665), the world was greatly shaken by a lawsuit that took place in Beijing. The lawsuit was the Kangxi Calendar Lawsuit (Kangxi Calendar Controversy) between the Jesuit priest and astronomer Johann Adam Schall von Bell (Tang Ruo wang 湯若望, 1591-1666) and Confucian writer Yang Guangxian 楊光先 (1597-1669).

Yang Guangxian (hereinafter referred to as Yang) openly framed the charges against Schall and obtained secret help from the four regents at the time. Unlike the many intellectuals who criticized Catholicism during the late Ming Dynasty, he fought alone much of the time. Still, he won the case: Schall was thrown into prison and Datongli 大統曆 (The traditional Han Chinese Calendar) was restored. On the surface, the lawsuit appeared to be a dispute regarding the contradiction between the Chinese calendar and western calendar, but in reality, it was a bloody confrontation between two cultures. It is possible to account for the lawsuit on the grounds of culture psychology, national feeling and palace politics, but from a broader perspective, what truly stands out is the wide gap in concepts of life and the world, about which Yang was undoubtedly clear.

* Prof. Li Xuetao 李雪濤 is dean of the School of History at Beijing Foreign Studies University. He was the president of the Society for Cultural Interaction in East Asia in 2017-2018. The author thanks Shikai 史凱 (Xi'an) and Zach Lundquist (Beijing) for their help in translating. 


\section{The Attitude Towards History: Sympathetic Understanding}

The purpose of historical research lies in pursuing the truth of history rather than merely viewing historical events through the lenses of today's perspective. But before conducting any analysis or criticism, we need to layout the historical context. As such, we should first hold the right attitude towards historical figures, which means we should apply a sympathetic attitude in understanding them. Since we are most likely to draw hasty conclusions from isolated incidents if we become overly engaged in minor details, the only way we can thoroughly understand the truth of what happened and feel how historical figures felt is to put ourselves into the their positions.

In reviewing the first volume of A History of Chinese Philosophy 中國哲 學史 $(1934)^{1}$ written by the philosopher and historian Feng Youlan 馮友蘭 (Feng Yu-lan, 1895-1990), Chen Yinke 陳寅恪 (1890-1969), the historian and orientalist wrote that historical research should "closely understand" the ancients:

To closely understand means to go on a mental journey and fancy yourself being a contemporary of the ancients. Put yourself in a position of feeling their anguish and showing sympathy. If not, you cannot be expected to show impartiality in evaluating their ideas. ${ }^{2}$

It is interesting to note that despite the wide recognition of the above approach, few historians ever capture its essence in their research. Good historians do not make any assumptions based on their own predisposition. Rather, they go back to the original context, examine events and concepts, and understand history. Under this approach, written archives and historical background information become the starting point of sympathetic understanding. They help to correct common misconceptions and faulty judgments, and furthermore, reevaluate historical events and figures.

When reading $B u$ De $Y i$ 不得已 (I Have No Alternatives) by Yang, I put down the book every once in a while and "fancy" the feelings of anguish and desperation which the Confucian intellectuals experienced as they observed the fall of traditional morality. This study does not intend to reevaluate or reposition Yang, but what the author wishes to do is recreate the historical context of understanding him. As for value judgment, it is the next logical step.

The boldest preserver of Confucian ethics in his time, Yang strongly opposed Catholicism and the western calendar. No one else could have been

1 Feng Youlan, 1938.

2 Chen Yinke 2001, 279. 所謂真瞭解者, 必神遊冥想, 與立說之古人, 處於同一境界, 而對於 其持論所以不得不如是之苦心孤詣, 表一種之同情, 始能批評其學說之是非得失, 而無隔関 膚廓之論。 
more vigorous in criticizing the western impact than he was. In his point of view, if the western calendar had taken the place of Chinese calendar, the consequence would go far beyond any technical level. What would follow was the collapse of Chinese morality (Dao 道). To better understand this point, we need to look at the "Calendar Controversy" against its historical background. Understanding historical context, as we have noted, will give us the key to a true understanding of Yang and other Confucian intellectuals: deep down in their hearts, they were going through the anguish and anxiety over the predictable breakdown of traditional morality.

From the Sui and Tang 隋唐 period to the early Qing period, in other words from the $6^{\text {th }}$ century to 1905 , the imperial examination had existed for over one thousand years. Since the Ming Dynasty (1368-1644), the examination came to be based on the Confucian and historian Zhu Xi's 朱喜 (11301200) Sishu jizhu 四書集注 (Annotations to the Four Books), and all the candidates were required to "write for the sages" (dai shengren zhi yan 代聖 人之言) under the guidance of Neo-Confucianism. Thus, Chinese intellectuals were made the guardians of the so-called Rationalistic School. This largely accounts for Yang's reaction to Christian missionaries.

Facing the impact of western civilizations, Yang was an insightful spectator, a profound thinker, a skillful debater, and a strong protector of culture traditions. Through deep self-reflection and fighting, he became acquainted with Catholicism and the western calendar. We must not undervalue the complexity of his inner world.

Some researchers tend to label Yang as narrow-minded, stubborn and obsolete as they look at him from today's perspective and state of knowledge. Taking Yang out of his context, they list his highly emotional words, magnify his opposition towards Catholicism and seem to suggest that everything about him is wrong. Or they make assumptions based on predispositions and come up with hasty conclusions. Obviously, these researchers fail to realize that human nature in history is complex and tangled. Here sympathetic understanding offers a solution: it encourages researchers to carefully read historical materials for the reconstruction of historical context, in order to avoid creating simplistic interpretations of historical figures.

\section{Dao and Qi}

In the context of Chinese philosophy, Dao 道 and Qi 器 are two important concepts. According to I Ching 易經 (Book of Changes), Dao refers to the metaphysical, and Qi stands for the physical. They are to be understood in relation to each other. If we interpret Qi as things, or the entity, Dao can be rendered as principles responsible for the way things act. Early in the Song period, the relationship between Dao and Qi attracted wide attention in the 
field of academia, and many philosophers made their observations, among them was Zhu Xi and Lu Jiuyuan 陸九淵 (1139-1192, or Lu Xiangshan 陸象 山). Zhu Xi inherited Cheng brothers' (Cheng Hao 程影, 1032-1085 and Cheng Yi 程碩, 1033-1107) understanding of the Dao and Qi and believed these two philosophical notions were closely interrelated and equally important, ${ }^{3}$ while Lu Jiuyuan considered Qi inferior to Dao, the basis for all things. ${ }^{4}$

During the Late Ming and Qing period, the Italian Jesuit priest and one of the founding figures of the Jesuit China missions Matteo Ricci (15521610) came to China in 1583, and with them came the introduction of Christianity with western learning into China. The scientific and technological knowledge were met with conditional acceptance by many Chinese intellectuals, and yet the western thoughts met with strong resistance. This mixed reaction is what Zheng Guangying 鄭觀應 (1842-1921) called "Dao comes before Qi” (Dao ben Qi mo 道本器末). According to Zheng's own words, Dao signifies the ethical and moral code of Confucianism, while Qi represents western science and technology. As a result of the work of missionaries, Qi added desirable qualities to Chinese scholarly tradition. But it was not allowed under any circumstance to threaten the Dao, the very foundation of the feudal regime. Any attempt to transmit western ethics via Qi was bound to arouse strong opposition from the scholar-officials. On this recognition, Siku Quanshu Zongmu Tiyao 四庫全書總目提要 (Summery of the General Catalogue of the Imperial Collection of Four) characterizes western learning as follows:

Accuracy in astronomy and calendric calculations and skillful at technical work, Europeans certainly surpass the preceding generations. But their thoughts are unprecedentedly absurd and heterodox. It is significant that the Imperial Court allows the spread of some technological knowledge while

3 "Utensil is Tao, while Tao is the Utensil. Tao is not separated from the Utensil, and Tao is just the principle of the Utensil. For example, a chair is a Utensil. Being seated is the principle of this chair. The human body is a Utensil, and the language and action are the principles of the human body. Principle is only above Utensil, and the principle and Utensil are not separated from each other.”器亦道, 道亦器也。 道未嘗離乎器, 道亦只是器之理。如這交椅是器, 可坐便是交椅之理。人身是器, 語言動作便 是人之理, 理只在器上。理與器未嘗相離。Li Jingde 黎靖德 1986, Vol. 77, 1970.

4 "The acquisition of morality is primary, the comprehension of skill is secondary, the acquisition of morality is put first, and the fulfillment is put after [...] Archery, chariot-riding, calligraphy and mathematics etc. are skills, which are humble, base, inferior and insignificant.” 德成而上, 藝成而下, 行成而先, 事成而後。.....凡射禦書數等 事, 皆藝也。爲卑鷂賤, 鷂下爲後。Sibu Congkan chubian 四部叢刊初編 2015, Vol.1161, juan 15, 2a-b. 
strictly prohibits western thought. ${ }^{5}$

It is clearly evident here that Chinese intellectuals, when compiling and editing Complete Library in Four Sections, were already concerned about the impact of the western Dao, fearing that it could readily shake the foundation of Chinese cultural tradition.

Viewed from today's perspective, such an idea of foreign culture, of course, shows neither confidence nor tolerance. Gone was a flexible and inclusive culture like that of the Han - Tang period (206 BC-220 AD, 618-907 AD). Out of the philosophical notion of "Dao governs Qi" emerged the “Ti-Yong theory" (Ti-Yong lun 體用論, taking Chinese learning as the essence, and western learning for practical use), which became a primary principle and method of the Self-Strengthening Movement (Ziqiang Yundong 自強運動) from 1861 to 1895 during the late period of the Qing Dynasty. The belief was that China should maintain its own style of learning to keep the "essence" of society, while at the same time using western learning for "practical use" in developing its infrastructure and economy. From the notion of "Dao governs Qi" to the theory of Ti-Yong, we can see just how the Ming and Qing intellectuals were feeling: being watchful against the western civilizations and at the same time worried about the decline of Sangang Wuchang 三綱五常 (three cardinal guides and five constant virtues, a standard of ancient Chinese feudalistic ethical order).

When discussing the impact of western civilization on the Far East, Arnold J. Toynbee (1889-1975) wrote that accepting a foreign culture was as hurtful as taking a risky task. In his words, those who had to withstand the impact would intuitively resist the new culture that showed signs of subverting social tradition. The resistance only made things even worse. ${ }^{6}$

It is possible to account for Yang's opposition to Christianity on the grounds that he felt intuitively that western learning showed a sign of “subverting social tradition”. The same seemed true for Zeng Guofan 曾國藩 (1811-1872), a leading figure in trying to prevent the downfall of the Qing regime, as the following quotes suggest:

Foreign countries excel at making machines, ships and cannons, but the western barbarians have little knowledge of rites and righteousness. How can they manage state and political affairs? What they call the statecraft is encouraging one to disobey his superiors and start a rebellion, to banish or even assassinate his emperor, to violate guides and morality. How dare they

5 Yongrong etc. 永瑢等 1965,1074 . 羅巴人天文推算之密, 工匠製作之巧, 實愈前古。其議 論誇詐迂怪, 亦為異端之尤。國朝節取其技能, 而禁傳其學術, 具有深意。

6 Cf. Toynbee, Arnold Joseph 1953, 81-82. 
talk about law?7

Although many neo-Confucian scholars took everything about Confucianism to the height of Dao and considered Qi (scientific and technological knowledge) to be the only noteworthy aspect of western learning, some reform-minded intellectuals thought differently and recognized the merits of the western Dao. Let us quote Tang Zhen 湯震 (Tang Shouqian 湯壽 潜, 1856-1917):

Chinese value Dao, or the metaphysical, while westerners specialize in Qi, or the physical. Chinese are so obsessed with Dao that they have crippled the ability to develop Qi. By contrast, it is not rare to see westerners focus on Qi and at the same time touch on Dao. Through a flexible approach, they advance Qi and ultimately move upward to Dao. If they can adapt our merits, why don't we learn from them?8

Be that as it may, it is not easy to integrate western learning with Chinese cultural tradition, for such an attempt has to deal with two different worlds of knowledge.

\section{Conflict in the Calendar Lawsuit}

The conflict between Chinese astronomers and western astronomers can be traced back to the last years of the reign of Emperor Shunzhi (1644-1661) when Johann Adam Schall von Bell, the German Jesuit and astronomer used his position in the imperial government to propagandize the western calendar. He tried to minimize the influence of the Chinese calendar by evaluating student astronomers on their knowledge of the western calendar, but his motive was not unchecked. During the Qing Dynasty, astronomical officials of the Imperial Astronomical Bureau fell into three groups: Han, Muslims and westerners. While astronomers of the Han ethnic people group adhered to Datong Li 大統曆 (the tradition Han Chinese calendar), Muslim astronomers formed a naturally different force of their religion. Soon after Schall became Director of the Imperial Astronomical Bureau, he removed the head of the Huihui ke 回回科 (the Muslim division) Wu Mingxuan 吳明炫 from office. In the $16^{\text {th }}$ and $17^{\text {th }}$ years of Emperor Shunzhi (1659-1660), Yang wrote Pi xie lun 辟邪論 (On Countering Heterodox) in three parts: Juxi Ji 拒西集 (Collection for Repelling the West), Zhaimiu Shilun 摘謬十論 (The Ten Propositions to Reveal Falsity) and Zhongxing Shuo 中星說 ( $O n$

7 Xuan Fan 宣牀 1910, 283. 彼外國之所長, 度不過機巧製造、船堅利炮而已。以夷狄之不知 禮義, 安有政治之足言。即有政治, 亦不過犯上作亂, 逐君斌君, 薉綱常、逆倫理而已, 又安足 法?

8 Tang Zhen 湯震 1993, 225. 蓋中國所守者形上之道, 西方所專者形下之器, 中國自以爲 道, 而漸失其所謂器; 西人畢力於器而有時暗合於道。彼既實而續之, 變而通之, 神而明之, 彼 能因我之所創, 我胡勿創彼之所因? 
Constellation). These essays signified his initial criticism of the western calendar and Catholicism. Although he made 5,000 copies of the first two essays for publicity, ${ }^{9}$ the imperial government did not pay much attention to it, most likely because Schall had close relations with Emperor Shunzhi and high officials. However, missionaries in the capital city began to feel threatened. Among them were Schall, the Italian Jesuit mathematician and theologian Ludovic Bugli (Li Leisi 利類思, 1606-1682) and the Portuguese Jesuit Gabriel de Magalhāes (An Wensi 安文思, 1609-1677), who founded the original St. Joseph's Church in Peking. Under their instructions, Li Zubai (李 祖白, 1610-1665), a catholic convert and astronomical official published Tianxue Chuangai 天學傳概 (A Summary of the Spread of the Heavenly Teaching) in 1663. The book was designed to refute Yang's Pi Xie Lun (On Countering Heterodoxy), but it was this book that provided Yang with a good excuse to further criticize Catholicism.

Emperor Shunzhi died in 1661 and was succeeded by Emperor Kangxi 康熙 (1662-1722). The new emperor was so young that the government had to be overseen by four regents. Obviously, it was the time for Yang to bring down Schall. In July of the $3^{\text {rd }}$ year of Emperor Kangxi, 1664, Yang sent to the imperial government Qing Zhu Xiejiao Zhuang 請誅邪教狀 (Plaint against Heterodox Teachings), Zheng Guoti Cheng Gao 正國體呈稿 (Draft of Memorial for the Safety of the Country) and Yu Xu Qingyu Shiyu Shu 與許清 嶼侍御書 (A Letter to the Censor Xu Qingyu), in which he accused Schall and his followers of plotting a revolt, deceiving people with the heretical books and throwing discredit on Chinese rites and ethics. He pleaded with the government to eliminate Catholicism straight away. Later he presented Zhaimiu Shilun (The Ten Propositions to Reveal Falsity) and Xuanze Lun 選 擇論(On the Selection) in which he fiercely criticized the western calendar and claimed that Schall was responsible for a series of misfortunate events because he had chosen the wrong date for the burial of Prince Rong 笨親王 (son of Emperor Shunzhi and Consort Donggo 董鄂妃, 1639-1660).

The Ministry of Rites (Libu 禮部) accepted the case and the investigation continued on through the autumn of the $3^{\text {rd }}$ year of Emperor Kangxi in 1664 to the following spring of 1665 . The Ministry of Rites and the Ministry of Personnel (Libu 吏部) jointly conducted the first hearing of the trial. Then the Ministry of Punishment (Xingbu 刑部), the Censorate (Duchayuan 都察院), the Supreme Court (Dalisi 大理寺) carried out the second hearing of the trial. During the third hearing, an imperial panel made up of Princes, Regents, Grand secretaries (Daxueshi 大學士), heads of ministries (Liubu Jiusi Zhangguan 六部九寺長官) and the commanders-in-chief of the eight banners

9 Yang Guanxian 楊光先 2000, 12. 
(Baqi Dutong 八旗都統) gave the ruling. ${ }^{10}$ Schall and seven other Christian astronomers were found guilty and sentenced to death. The day after the sentence was pronounced, a severe earthquake hit Beijing and the aftershocks recurred for several days. The earthquake worried the consorts and concubines, so much, that they believed it to be a warning from Heaven and persuaded the imperial government not to execute the astronomers. ${ }^{11}$ As a result, Schall and three other Jesuits, i.e. Ferdinand Verbiest (Nan Huairen 南 懷仁, 1623-1688), Ludovic Bugli, and Gabriel de Magalhāes were released from prison and permitted to live in Beijing as they had previously, but they were no longer allowed to preach to Chinese. In addition to this, other missionaries, including 21 Jesuits, 3 Dominicans and 1 Franciscan were exiled to Macau. Actually, before the lawsuit took place, Schall had experienced a stroke that left him unable to speak. Consequently, Verbiest had to answer questions for him during the trial. ${ }^{12}$ One year later, he died at the age of 75 on July $15^{\text {th }}$ in the $5^{\text {th }}$ year of Emperor Kangxi (1666).

The lawsuit settled, Yang was appointed Director of the Astronomical Bureau. Even though he was reluctant to take the post, the imperial government compelled him to accept it anyway. After he took office in August of the $4^{\text {th }}$ year of Emperor Kangxi, he restored the use of the traditional Chinese calendar. However, based on a test, Emperor Kangxi chose the western calendar over the Han calendar and Muslim calendar. In May of the $8^{\text {th }}$ year of Emperor Kangxi in 1669, Emperor Kangxi arrested Oboi (Aobai 鰲拜, c. 1610-1669), the ambitious regent who had established a system of near absolute rule under himself. Verbiest took this opportunity to present a memorial asking for the reopening of the reinvestigation of the Calendar Lawsuit. In August, the Qing government made the judgment that Yang fabricated charges against Schall. He was sentenced to death, only to be exiled to his native village due to his old age. He died at the age of 73 in Dezhou 德州, Shandong province, during his journey home. With his death, the Calendar Lawsuit finally came to an end.

\section{Influence of the Calendar Lawsuit}

The decade in which Emperor Shunzhi reigned might be seen as a fruitful period of Catholicism in China. Out of appreciation of Schall's work, Emperor Shunzhi adopted a less restrictive attitude toward Catholicism. He provided land for building churches and wrote the inscriptions in person. A

10 Regarding the trial, the details in Johann Adam Schall von Bell S.J. are quite detailed. Väth, Alfons 1933, 295ff.

11 Huang Bolu 黃伯祿 1904, 46a.

12 Ebd., 45b. 
direct benefit of that was seen in the quick growth in the number of churches and believers. According to Italian researcher Pasquale D'Elia (1890-1963), by the $7^{\text {th }}$ year of Emperor Shunzhi, China had 30 churches with 150 thousand Catholic converts, an increase from 2,500 in 1610 when Matteo Ricci died. ${ }^{13}$ However, it is worth pointing out that Emperor Shunzhi never issued an imperial decree that allowed Catholics to preach in China, nor did he ever convert to the Catholic faith. In Yuzhi Tianzhujiao Beiji 御制天主堂碑記 (Imperial Inscription of Catholics Church), he wrote, "What I admire is the teaching of Confucianism; what I pursue is to be single-minded in building ethics and practicing the doctrine of the mean. I tried to read books on Taoism and Buddhism, but did not find myself interested in them. When it comes to western books and Catholic doctrine, not a single book have I read. How can I know what Catholicism is all about?"14 Clearly, although Schall gained the personal confidence and trust of Emperor Shunzhi, Catholicism didn't capture the emperor's heart at all.

After the Calendar Lawsuit, Emperor Kangxi took the reins of power into his own hands. The case was reinvestigated and all findings were reversed. Schall was found not guilty and missionaries were appointed to posts in the imperial government. Despite this turn of events, they were forbidden from spreading Catholicism, dealing a heavy blow to Catholicism in China. It is not difficult to see here that Emperor Kangxi was influenced by Yang's opposition to Catholicism. From then on, a clear distinction was made between Catholic doctrine and western scientific knowledge. The missionaries holding positions in the Qing Court were banned from Christian missions. The aftermath can be seen in the Rites Controversy.

Yang wrote:

Thousands of people believe in Catholicism in Macau. They established a stronghold there and keep in touch with westerners across the sea. Under the cover of calendric affairs, Schall collects secret information of the government. Were it not for plotting the revolt, why would he meet people so often, build churches in the capital city and other strategic places and deceive people with the heterodox book? 15

As far as national security was concerned, Emperor Kangxi could not turn

13 D’Elia 1934, 67.

14 Huang Bolu 黃伯祿 1904, 21a-b. 夫朕所服膺者, 堯舜周孔之道; 所講求者, 精一執中之 理。至於玄笈貝文所稱道德、楞嚴諸書, 雖嘗涉獵, 而旨趣茫然。況西洋之書、天主之教, 朕素 未覽閱, 焉能知其說哉!

15 Yang Guanxian 楊光先 2000, 3. 香山澳盈萬人, 據為巢穴, 接渡海上往來。若望借曆法以 藏身金門, 窥伺朝廷機密。若非內勾外連, 謀為不軌, 何故布黨、為立天主堂於京省要害之地, 傳妖書以惑天下之人? 
a blind eye towards Yang's accusations. ${ }^{16}$ During the early years of the reign of Emperor Kangxi, unrest and chaos were not rare occurrences. In the southern provinces of Yunan 雲南, Guangdong 廣東 and Fujian 福建, the military forces of feudatories were growing; in the province of Taiwan 臺灣, the forces of Zheng Chenggong 鄭成功 (1624-1662), better known internationally by his Dutch-Romanized Hokkien honorific Koxinga or Coxinga, opposed the imperial Qing government. As such, Emperor Kangxi undoubtedly became alarmed at Yang's charges. Although no evidence of revolt was found, Emperor Kangxi decided to be cautious towards the missionaries. Taking the suggestion of his ministers, he issued an imperial decree that banned churches and missions across China.

Yang's accusations against Jesuits were largely a matter of "making sense out of something senseless", but they provoked the alarm of the imperial government. Consequently, the government imposed restrictions on missions and appointed a Manchurian to be the director of the imperial Astronomical Bureau.

\section{Conclusions}

Viewed from a modern day's perspective, Yang's opposition to Catholicism led to a large block against cross cultural communication. But he hit the nail on the head when he pinpointed the conflict between Catholicism and Chinese sociocultural concepts, in particular, Confucian ethical and moral code. He intuitively felt the threat to Confucianism. In his point of view, Christianity imposed the danger of subverting the very foundation of Chinese society. During the last few years of the reign of Emperor Kangxi, Catholicism was officially prohibited in China, but Yang was not directly responsible for it. The major cause was the Chinese Rites Controversy, a dispute about whether Chinese rites and offerings to the heaven, ancestors and the sages constituted idolatry. The focus was over the adoption of local practices of non-Christian countries.

On the surface, Ferdinand Verbiest and other missionaries won the contest between Schall and Yang. The victory, however, belonged to Yang and the Confucian ethics which he defended. A witness is the fact that the Manchu imperial government did not follow in the footsteps of western culture. Rather, it inherited the traditional traditions of the Han Chinese culture. It is in Yang's protection of Chinese Dao that we find his great merits.

\section{References}

Chen Yinke 陈寅恪, “Feng Youlan Zhongguo Zhexue Shi Shangce Shencha

16 Ebd., 2. 
Baogao” 冯友兰 《中国哲学史》上册审查报告 (Reviwing the First volume of A History of Chinese Philosophy by Feng Youlan), in: Chen Yinke, Jinmingguan Conggao Erbian 金明馆丛稿二编 (The Second Volume of Jinming Study Chamber), Beijing: SDX Joint Publishing Company, 2001.

D’Elia, Pasquale 德禮賢, Zhongguo Tianzhujiao Chuanjiaoshi 中國天主教傳教史 (Catholic Ntive Episcpacy in China), Shanghai: The Commercial Press, 1934

Feng Youlan 馮友蘭, Zhongguo Zhexue Shi 中國哲學史 (A History of Chinese Philosophy). Shanghai: The Commercial Press, 1934.

Huang Bolu 黄伯禄, Zhengjiao Fengbao 正教奉堡 (Praise documents to the Catholic church), Shanghai: Cimu Tang, 1904.

Li Jingde 黎靖德, Zhuzi Yulei 朱子語類 (Classified Conversations of Zhu Xi), Beijing: Zhonghua Shuju, 1986.

Sibu Congkan Chubian 四部叢刊初編, “Yu Tao Zanzhong”與陶贊仲 (Letter to Tao Zanzhong), in: Xiangshan Xiansheng Quanji 象山先生全集 (The Complete Works of Xiangshan), in: Sibu Congkan Chubian 四部叢刊初編 (Chinese Classics in the four categories, part 1), Shanghai: Shanghai Shudian, 2015, Vol.1161, juan 15, p. 2a-b.

Tang Zhen 湯震, Weiyan. Zhongxue Diliu 危言・中學第六 (Cautious words. Chapter 6: Chinese Academics), in: Xiaoshan Wenshi Ziliao Xuanji (Si). Tang Shouqian Shiliao Zhuanji 蕭山文史資料選輯(四) 一 湯壽潛史料專輯 (Selected Collections of Xiaoshan Literature and History (4) — Tang Shouqian Historical Materials Special Collection), Xiaoshan: Zhe Chu Shu Lin 浙出書臨 (90), No.59, 1993.

Toynbee, Arnold Joseph, The World and the West. NY and London: Oxford University Press, 1953.

Väth, Alfons, Johann Adam Schall von Bell S.J. Missionar in China, kaiserlicher Astronom und Ratgeber am Hofe von Peking 1592-1666. Ein Lebens- und Zeitbild. Veröffentlichungen des Rheinischen Museums in Köln, Zweiter Band. Köln: Verlag J. P. Bachem G.m.b.H. 1933.

Xuan Fan 宣樊, “Zhengzhi zhi Yinguo Guanxi Lun” 政治之因果關係論 (Theory of causality in politics), in: Dongfang Zazhi 東方雜誌 (The Eastern Miscellany), Vol. 7, No. 12, 1910.

Yang Guanxian 楊光先, Bu De Yi 不得已 (I Have No Alternatives). Hefei: Huangshan Shushe 黃山書社, 2000.

Yongrong etc. 永瑢等, Siku Quanshu Zongmu Tiyao 四庫全書總目提要 (Summery of the General Catalogue of the Imperial Collection of Four). Beijing: Zhonghua Shuju, 1965. 
